\title{
Chapter 21 \\ Evaluation of the Effect of the Wadi Bih Dam on Groundwater Recharge, UAE
}

\author{
Mohsen Sherif, Abdel Azim Ebraheem, Ampar Shetty, \\ Ahmed Sefelnasr, Khaled Alghafli, and Mohamed Al Asam
}

\begin{abstract}
In Ras Al Khaimah, UAE, groundwater from the alluvial aquifer in Wadi Bih was the only source of freshwater for various uses prior to the construction of a seawater desalination plant in 1998. This study was conducted to evaluate the effect of the Wadi Bih dam on groundwater resources and to increase knowledge of the hydrodynamics of the aquifer. A local-scale numerical groundwater flow model was developed and used to investigate the impacts of different groundwater management options on groundwater resources. The calibrated and validated model was defined as the base case, and subsequently, simulations were performed to analyze different management scenarios. The simulations indicated that maximum recharge occurred during years of high rainfall (1995-1998). Minimum recharge occurred in 2000, 2002, and 2004. The major contribution to the water balance was from subsurface inflows from the upper wadi zone and the two tributaries. Overall, the annual water balance was negative in most years, with an average net decline of $0.6 \mathrm{MCM}$ per year, indicating a slow but continuous depletion of groundwater resources. At the end of the simulation, the total groundwater recharge due to rainfall and water storage in the ponding area was 9.81 MCM.
\end{abstract}

M. Sherif · A. A. Ebraheem - A. Shetty $\cdot$ A. Sefelnasr $(\square) \cdot$ K. Alghafli

National Water and Energy Center, United Arab Emirates University, P.O. Box 15551,

Al Ain, UAE

e-mail: ahmed.sefelnasr@uaeu.ac.ae

M. Sherif

e-mail: msherif@uaeu.ac.ae

A. A. Ebraheem

e-mail: abdelazim.aly@uaeu.ac.ae

K. Alghafli

e-mail: khaledalghafli@uaeu.ac.ae

M. Sherif

Civil and Environmental Engineering Department, College of Engineering, United Arab

Emirates University, P.O. Box 15551, Al Ain, UAE

M. Al Asam

Department of Water Resources, Ministry of Energy and Industry, Dubai, UAE

e-mail: moh.alzaabi@aurak.ac.ae

(C) The Author(s) 2022

T. Sumi et al. (eds.), Wadi Flash Floods, Natural Disaster Science and Mitigation

Engineering: DPRI Reports, https://doi.org/10.1007/978-981-16-2904-4_21 
Keywords Managed aquifer recharge (MAR) - Recharge dam • Numerical groundwater flow model • Wadi Bih • UAE

\subsection{Introduction}

Natural water resources are scarce in arid and semiarid regions where evaporation significantly exceeds precipitation. Due to the absence of permanent surface water sources in such regions, groundwater constitutes the main source of irrigation water. Groundwater depletion poses a significant threat to water security in arid and semiarid areas, where rivers are usually ephemeral and groundwater is the main source of water. A growing population, rising standards of living, and water-intensive diets lead to an ever-increasing demand for freshwater, which causes considerable stress on groundwater resources. As a result, the overexploitation of groundwater has led to declining water levels in many aquifers in arid regions, such as UAE (Rizk and Alsharhan 2003). The groundwater pumped from these aquifers is attributed mostly to aquifer storage, which typically is not compensated through recharge processes. Generally, aquifer recharge in UAE is restricted to mountainous areas and alluvial gravels at the foothills of mountains. The natural aquifer recharge in UAE is estimated at 174 million $\mathrm{m}^{3}$, while the agricultural sector only consumes approximately 2.9 billion $\mathrm{m}^{3}$ through groundwater pumping (EAD 2018). In the mountains, floods are generated from heavy rainfall. A small portion of rainwater percolates into the subsurface, and thus, relatively large flood discharges are produced in wadi channels. The mean annual runoff of major wadis in UAE is approximately $120 \mathrm{MCM}$ (Sherif et al. 2018; Murad et al. 2020). Factors affecting the recharge efficiency include, among others, the geological conditions, hydrogeology, and hydrogeochemistry of the recharge sites, physiography, hydraulic gradients, vegetation cover, types of soil, gravels and loose sediments, fractures and joints, and the secondary porosity of consolidated sediments and rocks. A number of issues are known to reduce recharge efficiency over time, with the key issues being sedimentation and consistently high evapotranspiration.

Consequently, strategies to conserve groundwater and augment the amount of groundwater available for abstraction have gained growing attention over the last decades, with managed aquifer recharge (MAR) being considered an important tool in integrated water resources management (IWRM) (Dillon and Arshad 2016).

One type of MAR technology involves the construction of dams within wadi systems to trap and store surface runoff from flood events for subsequent infiltration to enhance groundwater recharge (Jaafar 2014; Missimer et al. 2015). Wadis are ephemeral streams in arid and semiarid regions, including the Middle East, northern Africa, and southwest Asia (Maliva and Missimer 2012). Typically, alluvial aquifers that occur beneath wadi channels are frequently used to supply water to villages and agricultural areas (Missimer et al. 2015). 
In Ras Al Khaimah City, UAE, groundwater abstraction from an alluvial aquifer in Wadi Bih was the only source of freshwater for domestic and other uses before the construction of a seawater desalination plant in 1998. In 1982, the Wadi Bih dam was constructed with the purpose of reducing the risk of flooding and increasing groundwater recharge to the aquifer. However, since the 1990s, a deterioration of the water quality has been observed, which might be attributed to the water mixing with a regional brine that may have increased in volume due to declining water tables resulting from abstractions (Rizk et al. 2007). A growing demand for new settlements and industrial activities as well as for agricultural production puts additional pressure on the groundwater resources in Wadi Bih. The main objective of this study was to assess the effect of the recharge from Wadi Bih dam on the groundwater resources in Wadi Bih. The dam efficiency has not been studied before; however, with increasing pressure on water resources and the observed deterioration of water quality, an improved knowledge of the dam-induced changes to the water balance and the available groundwater resources was deemed necessary to improve groundwater management in the area. As no groundwater-monitoring data from the predam period were available, a simple comparison of pre- and postdam groundwater levels was not possible. Therefore, a numerical groundwater flow model was developed with the additional objectives to reconstruct predevelopment conditions (i.e., no dam and no groundwater abstraction) to assess the effect of groundwater abstraction and the mitigating effect of the dam. These objectives will enable an evaluation of potential management scenarios for the sustainable management of Wadi Bih's groundwater resources.

\subsection{Hydrogeological Setting of Wadi Bih}

UAE lies in the southeastern part of the Arabian Peninsula, bounded on the north by the Arabian Gulf, on the south and west by the Kingdom of Saudi Arabia, and on the east by Oman and the Gulf of Oman (Fig. 21.1). A major part of the country is covered by sand dunes, but the northern part, where Wadi Bih is located, is characterized by mountains, gravel plains, and drainage basins.

Wadi Bih, in Ras Al Khaimah Emirate, is a large southwest-flowing wadi complex comprising parts of the Ruus Al Jibal Mountains of Oman in its eastern section and alluvial plains to the west and southwest. The drainage network of the Wadi Bih basin is mostly controlled by geologic structures. The wadi comprises an extensive network of valleys covering a surface area of $483 \mathrm{~km}^{2}$.

The catchment is marked by rough topography with steep slopes and very little vegetation. Elevations range from $2087 \mathrm{~m}$ above mean sea level at the highest point (amsl) to $65 \mathrm{~m}$ (amsl) near the outlet (Ebraheem et al. 2012; Sherif et al. 2018). The Wadi Bih drainage basin is rectangular in shape, and its drainage basin perimeter (water divide) is $113 \mathrm{~km}$ long. The upper portion of the basin consists of narrow valleys with steep slopes leading to distinct channels down to the wadi floor, which is composed of coarse alluvial gravels and boulders. The number and depth of the 


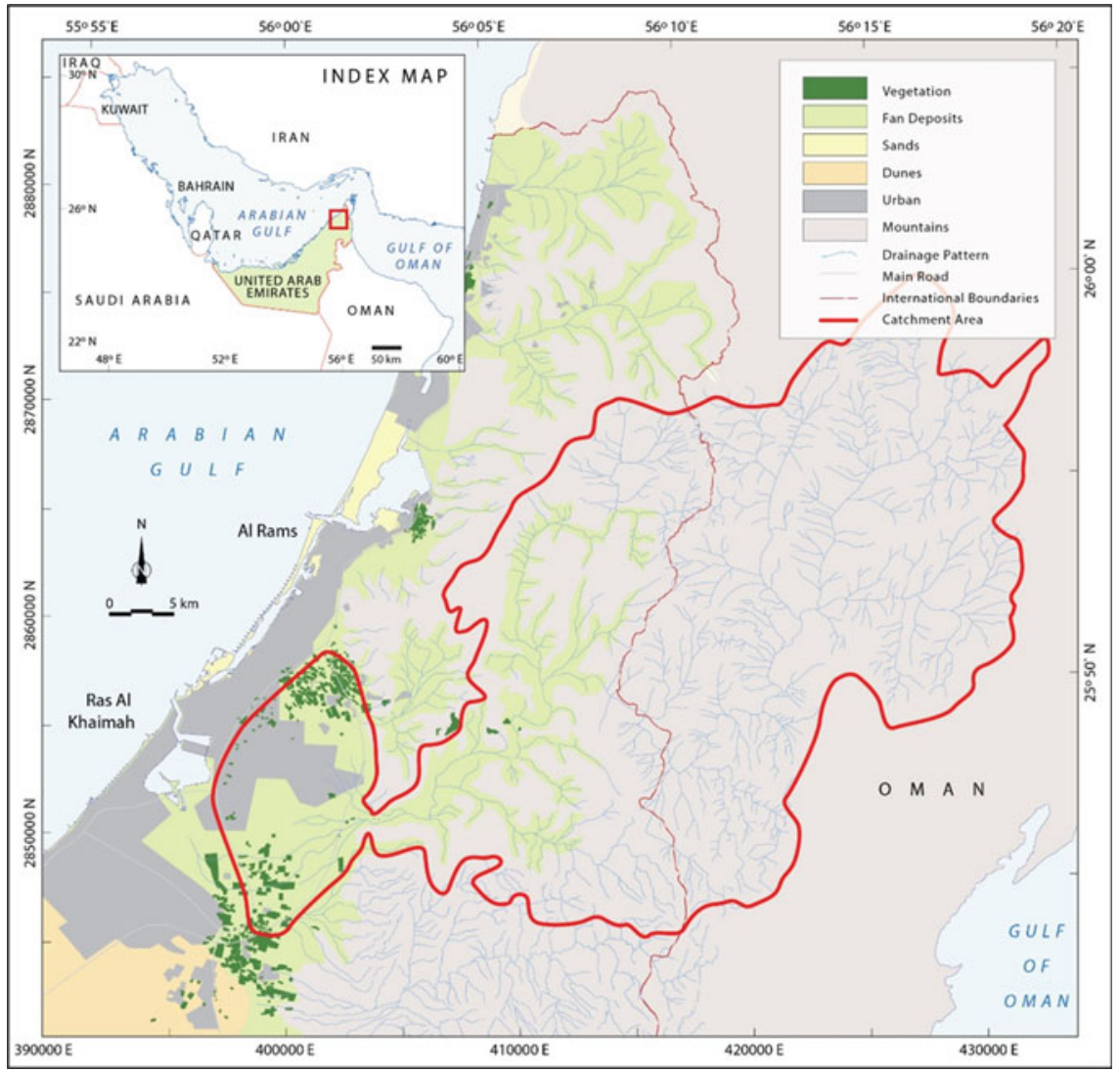

Fig. 21.1 Location and catchment area of Wadi Bih in Ras Al Khaimah Emirate (Source Ebraheem et al. 2012)

channels decrease toward the coast. The valley floor of Wadi Bih is a flat, gravelly plain with a triangular shape leading to an alluvial fan.

The catchment of Wadi Bih is mostly dry throughout the year, but occasional intense rainfall can lead to short-duration flash floods. The average annual rainfall in the catchment is $119 \mathrm{~mm} /$ year, varying between 6 and $414 \mathrm{~mm} /$ year. Rainfall records over the past 15 years indicate that the average annual rainfall has dropped to less than $70 \mathrm{~mm} /$ year (Sherif et al. 2009). The surface water flow is estimated to be approximately $1.72 \mathrm{MCM}$ and $10.35 \mathrm{MCM}$ at $3 \%$ and $18 \%$ of rainfall, respectively. The total annual rainfall in the area is 74 million $\mathrm{m}^{3}$, of which approximately $9 \%\left(6.7\right.$ million $\left.\mathrm{m}^{3}\right)$ recharges the karstified aquifer. This percentage increased to $13 \%$ (17.6 million $\mathrm{m}^{3}$ ) after the construction of the Wadi Bih dam in 1982 (Rizk 2015). On the other hand, the groundwater extraction from the Wadi Bih limestone aquifer decreased from an average of 9 million $\mathrm{m}^{3} / \mathrm{y}$ between 1991 and 1995 to 4.5 million $\mathrm{m}^{3} / \mathrm{y}$ between 2010 and 2014. The Wadi Bih dam is $18 \mathrm{~m}$ 
high and $240 \mathrm{~m}$ long and has a reservoir area of 3.2 million square meters (Ebraheem et al. 2012). The constructed storage capacity of the Wadi Bih dam is 7.5 MCM. However, the dam displayed a maximum storage of $6.50 \mathrm{Mm}^{3}$, encountered in July 1998 (Sherif et al. 2018), and the dam storage ranges from 0.5 to $2.7 \mathrm{MCM}$ in normal cases. The reservoir of the Wadi Bih dam is filled from time to time due to rain events; therefore, it acts as a mitigation measure and an MAR technique (Fig. 21.2).

The geology of Wadi Bih has been described in detail by Ebraheem et al. (2012). In short, Permian to Early Triassic dolomites and dolomitized limestones represent the main characteristics of the Russ al Jibal group. The sediments were deposited on the continental margin of Arabia as the Bih Formation, Hagil Formation, and Ghail Formation. These formations consist of well-bedded dolomite that is light to dark gray-colored and has frequent joints and fissures. A major fault runs through the dolomite in the north-south direction. The available drilling information from monitoring water wells was used to construct a subsurface geologic cross section, as shown in Fig. 21.3b. The alluvial cover varies in thickness but generally exceeds $80 \mathrm{~m}$ and consists of two units. The upper unit consists of loose, superficial Wadi gravels with a thickness ranging from 15 to $20 \mathrm{~m}$. The lower unit is composed of gravel- to boulder-sized debris and is partly cemented by calcite and silica. The depth of this layer base ranges from 80 to $160 \mathrm{~m}$ below ground level over the Wadi Bih area.

The aquifer system in the area around the Wadi Bih dam can be classified into two aquifer units: alluvial wadi gravels and underlying weathered and karstified limestone. The superficial gravel layer forms a highly permeable aquifer with variable hydraulic properties. The gravels tend to be unconsolidated near the ground surface, becoming more cemented and consolidated with depth. The wadi sediments range in size from silts to boulders and are derived from rocks within the catchment area. Drilling information from the study area indicates an average thickness of the alluvial cover of $80 \mathrm{~m}$. This alluvial cover can be divided into two units: the upper unit consists of loose gravels with boulders, and the lower unit consists of finer-grained gravels with clays and shales (Ebraheem et al. 2012). The weathered and karstified limestone of the lower aquifer unit has a relatively high groundwater potentiality. The estimated infiltration rate varies from 0 to $56 \mathrm{~cm} / \mathrm{h}$, and the lateral hydraulic conductivity ranges from 32 to $67 \mathrm{~m} / \mathrm{d}$ (Murad et al. 2017). The transmissivity of sediments in the area of interest ranges from 580 to $2800 \mathrm{~m}^{2}$ / $\mathrm{d}$, while the storage coefficient has been estimated at approximately 0.1 (MOEW 2010).

The aquifer system is underlain by consolidated rocks of the limestone Musandam Formation. Several small villages and farms that are located within the study area have their own wells and use groundwater for irrigation purposes. In addition, two well fields have been constructed to supply water for domestic use.

A hydrologic assessment shows that flash flood hazards in the Wadi Bih drainage basin are moderate. Flash flood events are repeated approximately every three to four years. The Wadi Bih dam mitigates flash flood hazards and increases the groundwater recharge potentiality in the vicinity of the dam. Floodwaters in wadis 

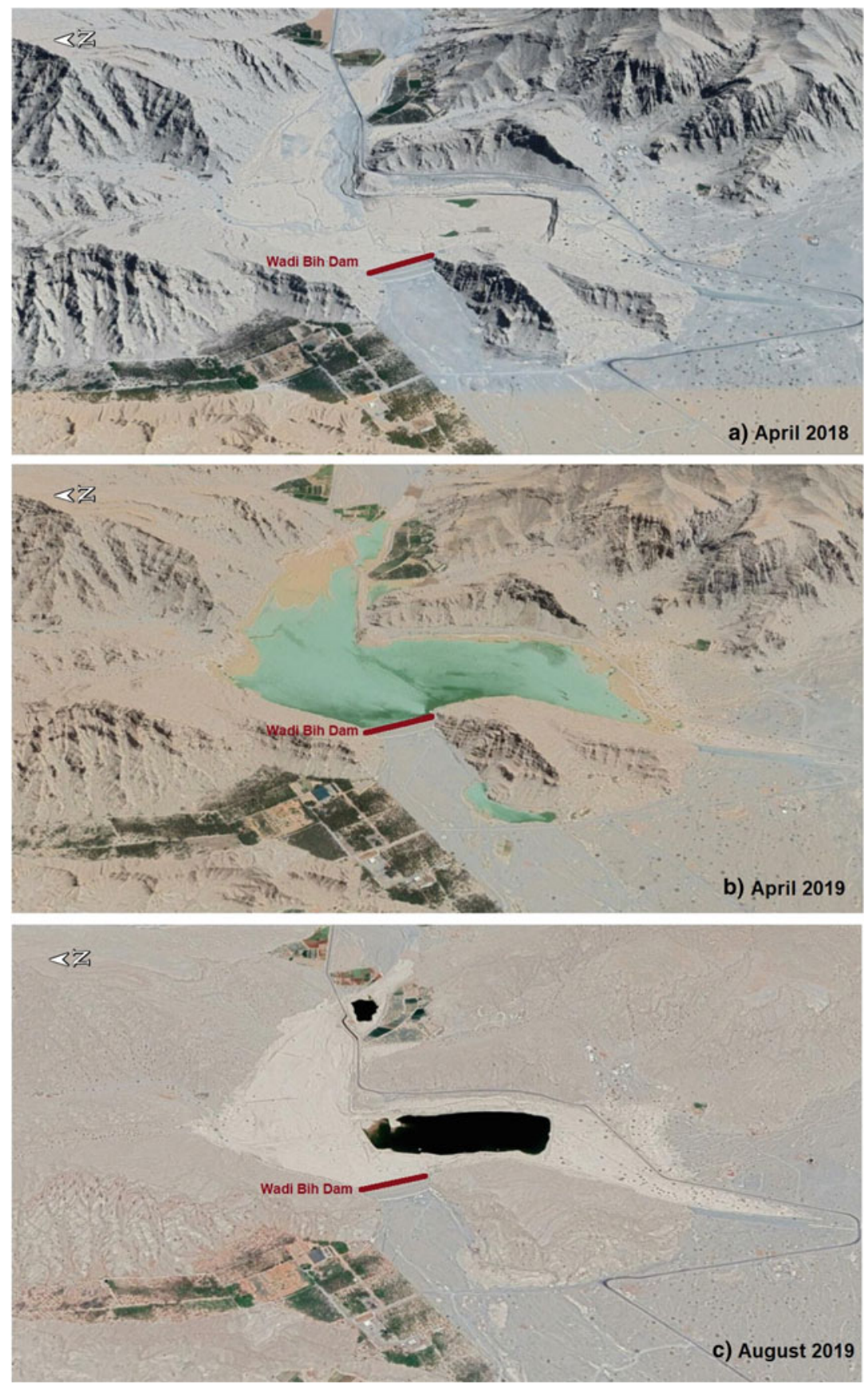

Fig. 21.2 Satellite images showing the Wadi Bih dam and reservoir in three successive time periods illustrating the reservoir before, during, and after filling with water 

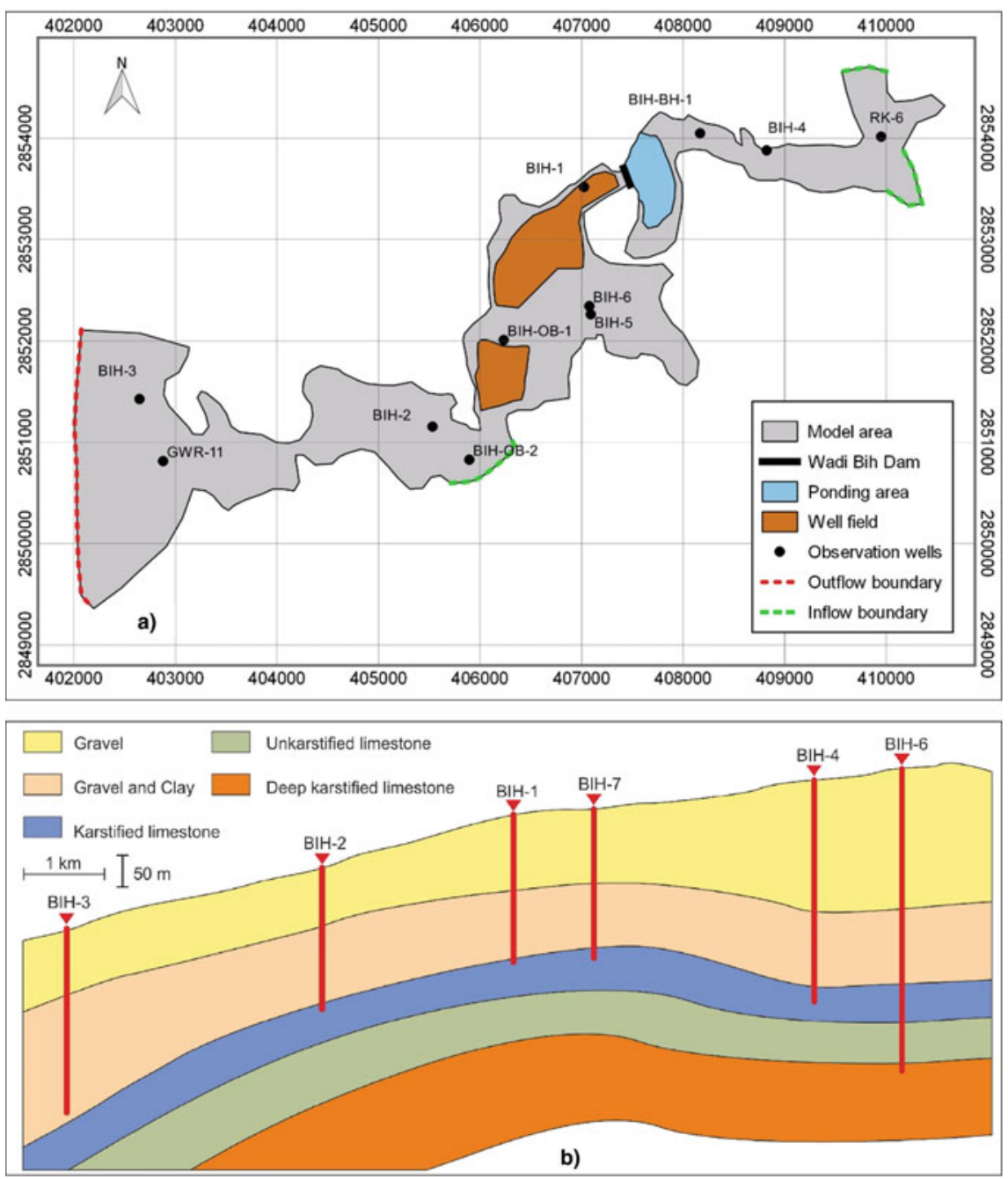

Fig. 21.3 A figure showing a the Wadi Bih model domain and locations of observation wells and b a cross section along selected wells

typically carry heavy sediment loads. As the floodwater is detained, these sediments settle, leading to clogging of the pore spaces in the upper layers of the reservoir's subsurface and the deposition of silts and sediments on the reservoir bottom. Periodic removal of these sediments enhances the percolation process of water. 


\subsection{Methodology}

A numerical groundwater model of the Wadi Bih dam area was developed, calibrated, and validated using MODFLOW (McDonald and Harbaugh 1988). The mathematical equations used to describe groundwater flow through a porous medium are based mainly on Darcy's law and the continuity equation, which can be described as follows (Freeze and Cherry 1979):

$$
\frac{\partial}{\partial x}\left(k_{x x} \frac{\partial h}{\partial x}\right)+\frac{\partial}{\partial y}\left(k_{y y} \frac{\partial h}{\partial y}\right)+\frac{\partial}{\partial z}\left(k_{z z} \frac{\partial h}{\partial z}\right)+q_{s}=s_{s} \frac{\partial h}{\partial t}
$$

where $K_{x x}, K_{y y}$, and $K_{z z}$ represent the hydraulic conductivity in the $x$-, $y$-, and $z$ directions, respectively; $h$ is the hydraulic head; $q_{s}$ stands for the source/sink term; $S_{s}$ refers to the specific storage; and $t$ describes the time. This equation can be further implemented using finite difference methods through a set of algebraic equations (discrete model) to solve certain groundwater problems.

The model includes the effects of the dam in the form of increased recharge rates across the ponding area and the effects of groundwater abstraction from well fields. In subsequent simulations, the dam and well fields were deactivated to analyze their effects. The methodology is described in more detail below.

\subsubsection{Conceptual Model}

The developed groundwater model focuses on the area downstream of the Wadi Bih dam and covers an area of $9.60 \mathrm{~km}^{2}$, as shown in Fig. 21.3a. The model area is bounded by limestone outcrops that act as no-flow boundaries. This boundary was justified because the depth to the groundwater in the area of interest is relatively high; hence, no horizontal flow occurs from the limestone to the Quaternary sediments of the wadi. However, the no-flow boundary is dissected by the wadi tributaries and the outlet of the wadi (green and red dotted lines in Fig. 21.3a, respectively). These were considered inflow and outflow boundaries, respectively. Available bore log information from 11 observation wells illustrated a distinct top unit of gravels and boulders, a middle unit of fine gravels with clay or shale with clay, and a bottom unit of fissured limestone. Three inflows to the modeled area exist, representing the main channel of Wadi Bih, the inflow from Wadi Qadaah, and the inflow from an unnamed tributary. The inflows were defined as specified flux boundaries. The outflow moves through the alluvial fan into the Arabian Gulf; this outflow was defined as a constant head boundary.

Localized recharge occurs through the ponding area of the dam, and diffuse rainfall recharge occurs across the remaining surface area of the model domain. Loss due to evapotranspiration from the water table was considered negligible as the depth to the water table was greater than the extraction depth. Groundwater 
abstraction occurs from two well fields located downstream of the dam with a total number of 38 pumping wells (Fig. 21.3a) and from several small farms located within the study area. Figure $21.3 \mathrm{~b}$ illustrates a subsurface cross section compiled from the bore data of available wells in the area.

\subsubsection{Numerical Groundwater Model Set up}

A cell size of $100 \times 100 \mathrm{~m}$ was selected for the numerical model, resulting in 90 columns and 60 rows. The net area of the modeled aquifer was then represented by 960 active cells. The aquifer system is composed of three units, which were represented by three model layers with a total thickness ranging from 80 to $160 \mathrm{~m}$. Specific yield and hydraulic conductivity values were obtained from pumping test data from the monitoring wells (Table 21.1). For each layer, the initial values were assigned through interpolation among the well locations, and the values were then adjusted during calibration. The constant head boundary representing discharge through the alluvial fan to the Arabian Gulf was set along the 0-m groundwater contour line. The inflows through the flux boundaries were initially estimated from water level fluctuations and were then adjusted during calibration.

Recharge to the aquifer was recognized in two zones corresponding to recharge from rainfall and localized recharge from dam storage for the modeling period. Rainfall recharge rates were assigned to all active cells in the model area by applying a recharge factor (i.e., the percentage of rainfall that becomes recharge) to the rainfall data obtained from the Bih rain gauge. These recharge factors were adjusted during calibration. For localized recharge, the ponding area of the dam was delineated for a medium water level, which summed up to an area of $0.31 \mathrm{~km}^{2}$.

Table 21.1 Calibrated hydraulic conductivity and specific yield values at observation well locations

\begin{tabular}{|c|c|c|c|c|c|c|}
\hline \multirow[t]{2}{*}{ Well } & \multicolumn{3}{|c|}{ Hydraulic conductivity (m/day) } & \multicolumn{3}{|c|}{ Specific yield } \\
\hline & Layer-1 & Layer-2 & Layer-3 & Layer-1 & Layer-2 & Layer-3 \\
\hline BIH-1 & 150.0 & 10.0 & 75.0 & 0.008 & 0.0001 & 0.02 \\
\hline BIH-2 & 100.0 & 10.0 & 50.0 & 0.001 & 0.0001 & 0.0005 \\
\hline BIH-3 & 100.0 & 10.0 & 50.0 & 0.001 & 0.00001 & 0.0005 \\
\hline BIH-4 & 150.0 & 75.0 & 75.0 & 0.008 & 0.001 & 0.001 \\
\hline BIH-5 & 100.0 & 75.0 & 75.0 & 0.008 & 0.001 & 0.001 \\
\hline BIH-6 & 100.0 & 75.0 & 75.0 & 0.008 & 0.001 & 0.001 \\
\hline BIH-O.B-1 & 150.0 & 75.0 & 75.0 & 0.008 & 0.001 & 0.001 \\
\hline BIH-O.B-2 & 150.0 & 75.0 & 75.0 & 0.008 & 0.001 & 0.001 \\
\hline BIH-B.H-1 & 150.0 & 75.0 & 75.0 & 0.008 & 0.001 & 0.001 \\
\hline BIH-RK-6 & 150.0 & 75.0 & 75.0 & 0.008 & 0.001 & 0.001 \\
\hline GWR-11 & 150.0 & 10.0 & 50.0 & 0.001 & 0.00001 & 0.0005 \\
\hline
\end{tabular}


Recharge rates were assigned to the cells within the ponding area based on the storage period and on a recharge factor applied to the rainfall data. The recharge factor was adjusted during calibration. Abstraction rates were initially estimated from abstraction data that was obtained from local authorities. As complete records were not available for all wells, these abstraction rates were also adjusted during calibration. Groundwater levels during December 1988 of all available observation wells were used to derive the initial head distribution in the study area, as groundwater extraction before 1990 was limited (Al Asam 1997; Rizk and Alsharhan 2003).

\subsubsection{Model Calibration and Validation}

The model was calibrated for the period between January 1989 and December 1993 and was subsequently validated with observed water level data from January 1994 to December 2004. Monthly groundwater level data from 7 observation wells were available for the comparison of the simulated heads with the observed heads. The model calibration was achieved by manually adjusting the following parameters (through trial and error): hydraulic conductivity, specific yield, recharge factors (percentage of rainfall), pumping rates, and inflow across boundaries. The model calibration and validation were evaluated using the following standard error statistics (Sorooshian and Gupta 1995): mean error (ME), root mean square error (RMSE), coefficient of determination $\left(\mathrm{R}^{2}\right)$, and Nash-Sutcliffe efficiency or model efficiency $(\mathrm{EF})$.

The mean error between the predicted values and observed values can be defined as follows $(\mathrm{i}=1$ to $\mathrm{N})$ :

$$
M E=\frac{1}{N} \sum_{i=1}^{N}\left(O_{i}-P_{i}\right)
$$

The standard deviation of the differences between the predicted values and observed values was represented by the root mean square error (RMSE) as follows:

$$
R M S E=\sqrt{\frac{1}{N} \sum_{i=0}^{N}\left(O_{i}-P_{i}\right)^{2}}
$$

The coefficient of determination $\mathrm{R}^{2}$ represents the squared value of the coefficient of correlation and can be described as follows:

$$
R^{2}=\left(\frac{\sum_{i=0}^{N}\left(O_{i}-\overline{\mathrm{O}}\right)\left(P_{i}-\overline{\mathrm{P}}\right)}{\sqrt{\sum_{i=0}^{N}\left(O_{i}-\overline{\mathrm{O}}\right)^{2}} \sqrt{\sum_{i=0}^{N}\left(P_{i}-\overline{\mathrm{P}}\right)^{2}}}\right)^{2}
$$


Nash and Sutcliffe (1970) described model efficiency as one minus the sum of the absolute squared differences between the predicted and observed values, normalized by the variance of the observed values along the period under interest, as follows:

$$
\begin{gathered}
E F=\frac{\sum_{i=1}^{N}\left(O_{i}-\overline{\mathrm{O}}\right)^{2}-\sum_{i=1}^{N}\left(O_{i}-P_{i}\right)^{2}}{\sum_{i=1}^{N}\left(O_{i}-\overline{\mathrm{O}}\right)^{2}} \\
E F=1-\frac{\sum_{i=0}^{N}\left(O_{i}-P_{i}\right)^{2}}{\sum_{i=0}^{N}\left(O_{i}-\bar{O}\right)^{2}}
\end{gathered}
$$

where $N$ is the total number of observations, $O_{i}$ is the observed groundwater level of the $i$ th observation, $P_{i}$ is the estimated groundwater level of the $i$ th observation, and $\bar{O}$ is the mean of the observed groundwater levels.

\subsubsection{Simulations}

The calibrated and validated model, which comprises groundwater abstraction as well as recharge from the dam and thus represents the actual conditions, was defined as the base case. Subsequently, simulations were performed to analyze the following cases.

\subsubsection{Effect of the Dam on Groundwater Recharge}

To study the effect of the dam on groundwater recharge, the model was run with the localized recharge from the ponding area switched off. The total recharged volume over the simulation period from January 1994 to December 2004 was computed and compared with the base case. The dam efficiency was calculated as the ratio of groundwater recharge from the ponding area to water storage in the reservoir, which was obtained from field observations.

\subsubsection{Impact of Present Exploitation}

To analyze the impact of the present exploitation of the aquifer, the model was run with all abstractions switched off, and the simulated water table was compared with the water table of the base case over the validation period. 


\subsubsection{Comparison of Predevelopment and Postdevelopment States}

A predevelopment state is characterized by the absence of both recharge from the dam and groundwater abstractions. To simulate this state, the recharge from the ponding area and all abstractions were switched off, and the simulated water table was compared with that of the base case representing the postdevelopment state.

\subsection{Results and Discussion}

\subsubsection{Calibrated Model Parameters and Model Performance}

The calibrated hydraulic conductivity values ranged from 100 to $150 \mathrm{~m} / \mathrm{d}$ in layer 1 and from 10 to $75 \mathrm{~m} / \mathrm{d}$ in layers 2 and 3 (Table 21.1). The specific yield values were approximately 0.008 in layer 1 and 0.001 in layers 2 and 3, with a total range from 0.00001 to 0.02 (Table 21.1).

The calibrated rainfall recharge factor is $20 \%$ of rainfall. This value falls within the reported values for alluvial gravels in UAE (IWACO 1986; MGGS 1996). The existence of sands and gravels in the studied aquifer system area permits such aquifer recharge. Field observations also indicated the direct effect of rainfall events on groundwater levels (Ebraheem et al. 2012). The localized recharge due to storage in the ponding area was calibrated to $25 \%$ of rainfall. Calibrated groundwater abstraction rates increased significantly from 1998. The highest abstraction rates occurred in 2000. After 2001, abstraction rates were steady. The calculated versus observed groundwater levels are represented in Fig. 21.4 for four selected observation wells. As illustrated by the figure, the model very closely simulates the groundwater levels that developed due to groundwater extraction and recharge from dam storage and rainfall events. However, a few discrepancies are apparent, which may be attributed to the accuracies of the observed groundwater levels that used to be measured only once every month and not necessarily on the same day each month. For the validation period, the simulated groundwater levels are also in good agreement with the observed records (Fig. 21.4), confirming that the model can represent the given conditions in the study area.

The predicted and observed water levels were evaluated with standard tests for both the calibration and validation periods. Table 21.2 provides relevant statistics related to the observed and simulated groundwater levels during the calibration and validation periods. The differences between the means, maximums, minimums, and standard deviations of the predicted and observed values are very small for both the calibration and validation periods. The coefficient of determination, $R^{2}$, is very close to one in both periods. Apart from high $R^{2}$ values, it is prudent to consider additional information provided by the gradient and the intercept of the regression on which the $R^{2}$ is based. In the present case of the calibration and validation 

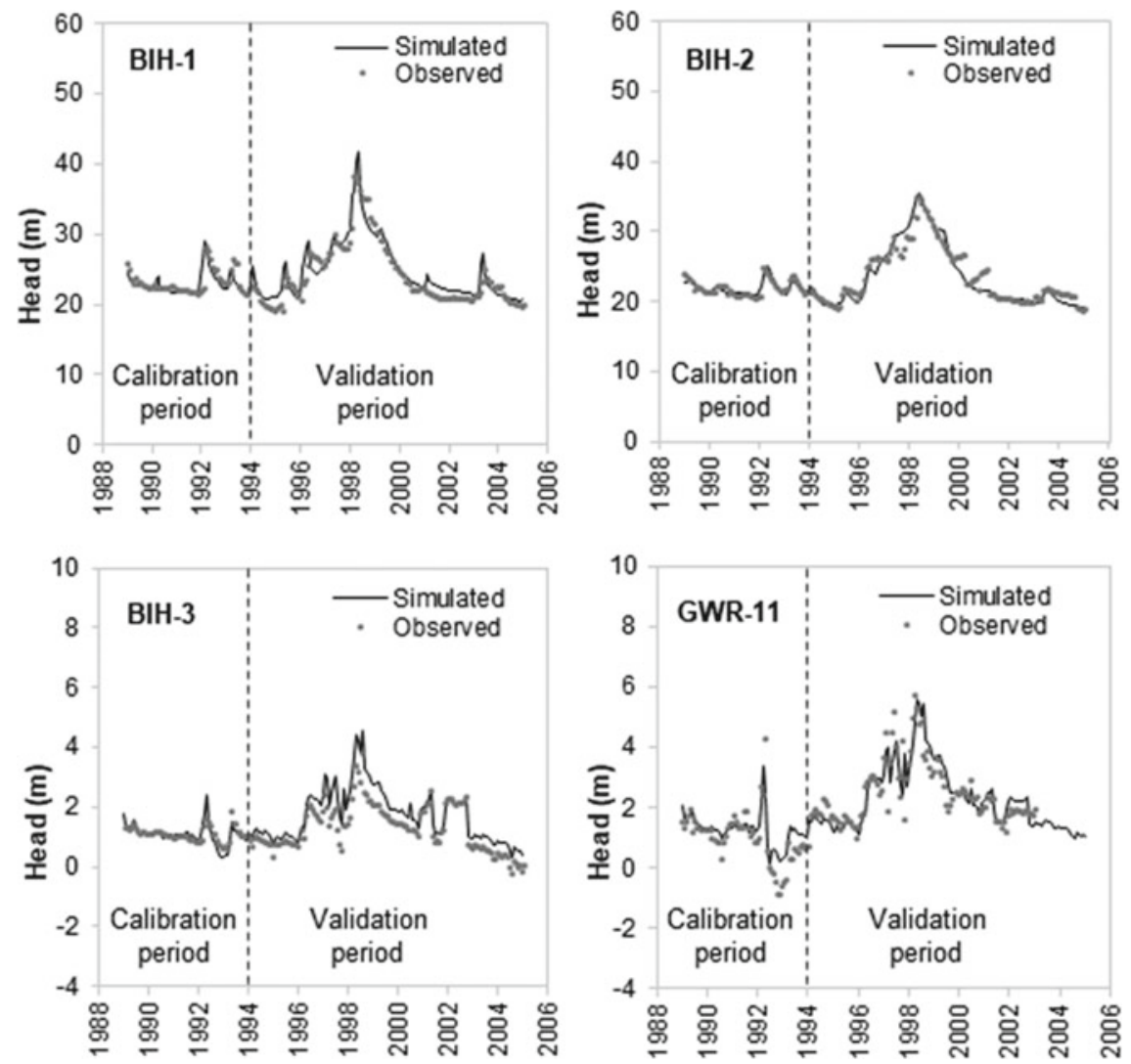

Fig. 21.4 Observed and simulated hydrographs at four observation wells

periods, good agreement of this intercept was observed (Fig. 21.5). The intercept is close to zero, which means that an observed head of zero would also result in a prediction near zero. The gradient is very close to one, showing that the observed and predicted values are very close to each other (Fig. 21.5). Furthermore, the mean error (ME) and RMSE values for the calibration and validation periods are acceptably low (Table 21.2). The model efficiency (EF) estimates the error relative to the natural variation in the observed values; the $\mathrm{EF}$ varies from $-\infty$ to 1.00 . The EF becomes zero in the case that the square of errors between the predictions and observations equals the variation of the observations. Values of $0.50 \leq \mathrm{EF} \leq 1.00$ are deemed satisfactory (Singh 2011). In this study, the EF values are 0.997 and 0.987 for the calibration and validation periods, respectively, showing good agreement between the predicted and observed groundwater levels. This agreement indicates that the developed model is fit to use for long-term predictions. 
Table 21.2 Statistical parameters of observed and simulated groundwater levels

\begin{tabular}{l|l|l|l|l|l|l}
\hline Parameter & \multicolumn{5}{|l|}{ Calibration period } & \multicolumn{2}{l}{ Validation period } \\
\cline { 2 - 7 } & $\begin{array}{l}\text { Observed } \\
(\mathrm{m})\end{array}$ & $\begin{array}{l}\text { Calculated } \\
(\mathrm{m})\end{array}$ & $\begin{array}{l}\text { Difference } \\
(\mathrm{m})\end{array}$ & $\begin{array}{l}\text { Observed } \\
(\mathrm{m})\end{array}$ & $\begin{array}{l}\text { Calculated } \\
(\mathrm{m})\end{array}$ & $\begin{array}{l}\text { Difference } \\
(\mathrm{m})\end{array}$ \\
\hline Max & 28.15 & 29.10 & 0.94 & 38.38 & 41.59 & 3.20 \\
\hline Min & -0.87 & 0.18 & 1.05 & 0.03 & 0.32 & 0.30 \\
\hline Mean & 11.70 & 11.68 & 0.02 & 16.38 & 16.50 & 0.13 \\
\hline STDEV & 10.81 & 10.67 & 0.14 & 11.49 & 11.17 & 0.32 \\
\hline ME & 0.027 & & 0.158 & & \\
\hline RMSE & 0.041 & 0.030 & & \\
\hline EF & 0.997 & 0.986 & & \\
\hline $\mathrm{R}^{2}$ & 0.997 & 0.987 & & \\
\hline
\end{tabular}
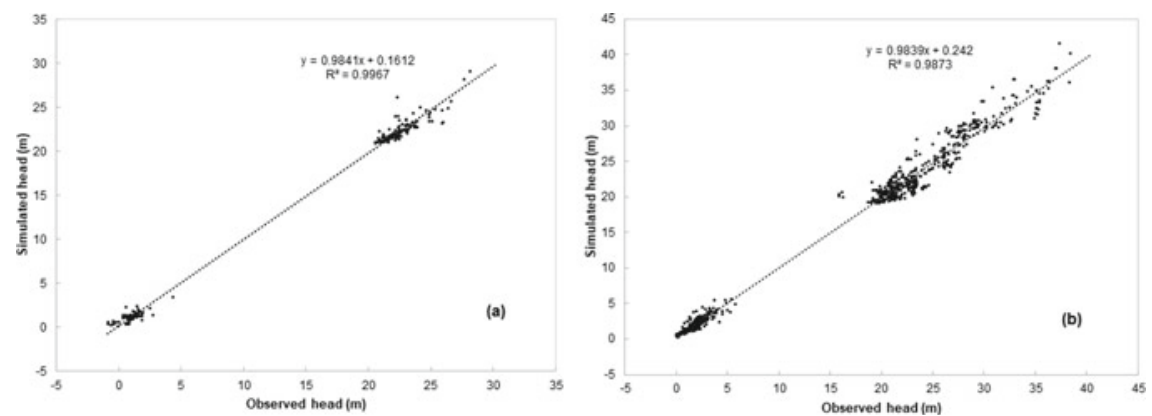

Fig. 21.5 Observed versus simulated heads for the $\mathbf{a}$ calibration period and $\mathbf{b}$ validation period

\subsubsection{Water Balance}

Yearly water balances derived from the model results over the validation period are shown in Fig. 21.6. Maximum recharge occurred during years of high rainfall (1995-1998). Minimum recharge occurred in 2000, 2002, and 2004. The major contribution to the water balance resulted from subsurface inflows from the upper wadi zone and the two tributaries. The net constant head outflow was greater during wet periods than during dry periods. The outflow storage component was also greater during wet periods. Groundwater abstraction increased from 1998 and peaked in 2000, which was a dry year. After that, abstraction remained relatively steady at a rate of approximately 4.3 MCM (million $\mathrm{m}^{3}$ ) per year. Overall, the annual water balance was negative in most years, with an average net decline of 0.6 MCM per year, indicating a slow but continuous depletion of groundwater resources. 


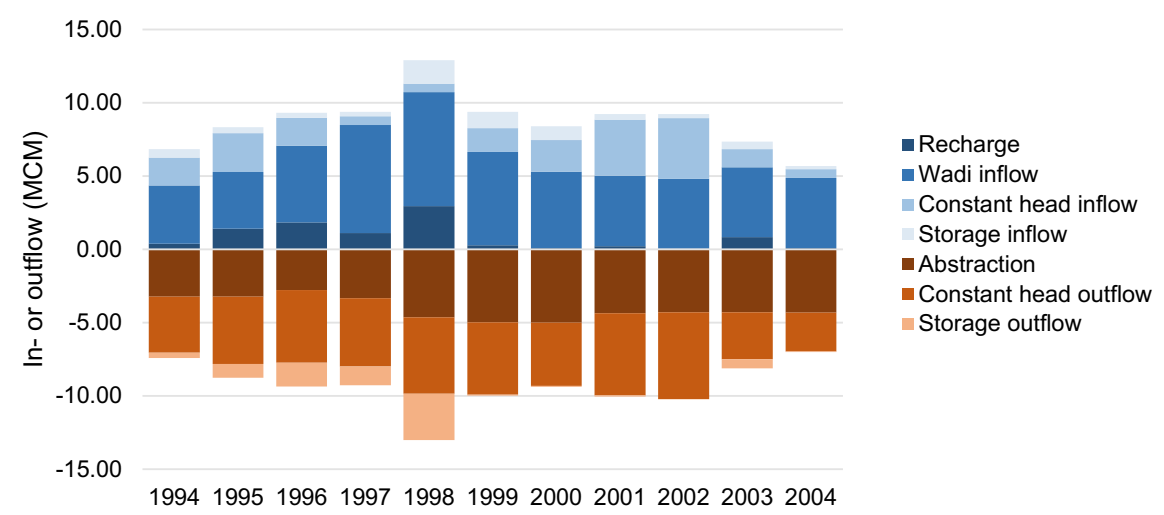

Fig. 21.6 Annual water balances derived from the groundwater model

\subsubsection{Effect of the Dam on Groundwater Recharge}

To evaluate the effect of the dam on replenishing the groundwater aquifer, a model simulation was conducted without the dam (i.e., no recharge from the ponding area), and the results were compared with the base case representing the actual conditions that included recharge from the dam. At the end of the simulation period (December 2004), the total groundwater recharge due to rainfall and water storage in the ponding area was 9.81 MCM (Fig. 21.6). Without the dam, the total simulated recharge was $2.58 \mathrm{MCM}$. Thus, the extra groundwater recharge caused by dam construction was 7.22 MCM over a period of 11 years and three months, representing $74 \%$ of the total recharge. These results indicate that the majority of groundwater recharge is due to infiltration from the water stored in the ponding area of the dam. This result can mainly be attributed to the increased duration of infiltration, as the average duration of ponding was 60 days per year, while direct recharge from rainfall only occurred during a few rain events per year.

The cumulative recharge curves shown in Fig. 21.7 further illustrate the effect of the dam on groundwater recharge. The figure also shows that the majority of recharge over the simulation period occurred throughout the wet period from 1995 to 1998. The total water storage in the ponding area was estimated to be 22.98 MCM over the simulation period. With the total recharge from the ponding area of 7.22 MCM, the efficiency of the dam, which is the ratio of groundwater recharge to storage, is $31.4 \%$. This result indicates that a major part of the water that infiltrates through the ponding area is stored in the unsaturated zone, resulting in an increase in the moisture content of the soil. Additionally, losses occur through evaporation from the reservoir. The efficiency of the Wadi Bih dam is a medium value compared to findings from other nearby dams. At Wadi Ham, approximately $100 \mathrm{~km}$ from the study area, the efficiency of the dam was found to be $47 \%$, and at Wadi Tawiyean $(50 \mathrm{~km}$ from the study area), it was approximately $22 \%$ (Sherif et al. 2017). 


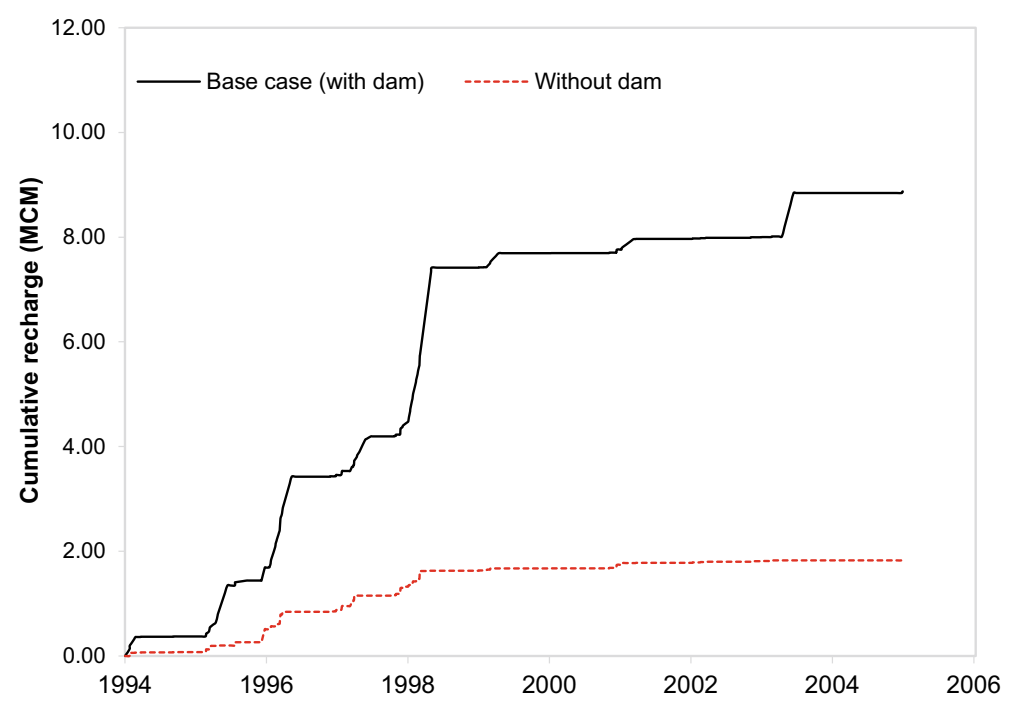

Fig. 21.7 Cumulative recharge with and without dam

\subsection{Impact of Present Exploitation}

The Wadi Bih model was employed to simulate the impacts of extraction from the well fields in the study area. For this simulation, the extraction values were excluded from the model, and the calculated water table was compared with the base case (Fig. 21.8). The results indicate that without abstraction, water levels would have reached much higher levels. The impact of groundwater abstraction is greater during periods of low groundwater recharge and low water levels. The minimum effects of abstraction are noticed during wet years (1995-1998). Additionally, the minimum impacts of abstraction occur close to the alluvial fan and away from the well fields (wells BIH-3 and GWR-11).

\subsubsection{Predevelopment Versus Postdevelopment}

A comparison between the predevelopment state (i.e., no abstractions and no dam) and the postdevelopment state (base case) shows that the peaking responses of the water levels in wells located near the ponding area of the dam are due to enhanced recharge from dam storage (Fig. 21.8). Without the dam, the water level response would be much smoother. The comparison also shows that the impact of the dam is small compared to the impact of abstraction. The dam is only able to compensate for a small proportion of the water table decline that occurs due to abstraction. After the wet period, the water table would have stayed at a high level without 

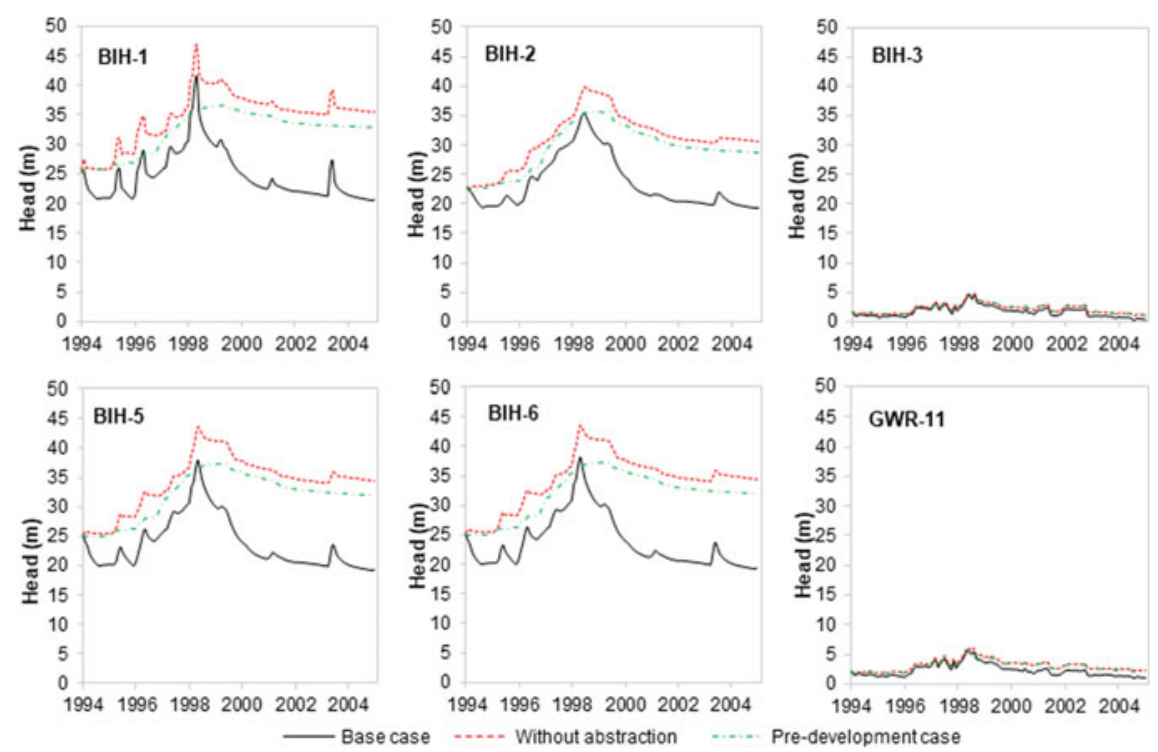

Fig. 21.8 Simulated hydrographs at selected observation wells representing the base case, the case without abstraction, and the predevelopment case (no dam, no abstractions)

abstraction. However, abstraction has led to a decline in the water table to a level prior to that observed during the wet period, with a trend that indicates further decline. At the wells located away from the dam and the well fields (BIH-3 and GWR-11), there are only small differences between pre- and postdevelopment. However, the postdevelopment groundwater levels approach sea level at these wells, which means that further declines in water levels may lead to intrusions of seawater and deterioration of the water quality.

\subsection{Conclusion}

A numerical groundwater model was developed to evaluate the effects of a groundwater recharge dam in Wadi Bih (UAE) on recharge rates and volumes. Furthermore, the model was employed to reconstruct predevelopment groundwater dynamics to analyze the impact of current groundwater exploitation and the combined impacts of abstraction and recharge from the dam on groundwater resources. Dam-induced recharge was found to have a strong effect on the aquifer's water levels, particularly during years with large amounts of rainfall. Recharge from the ponding areas of the dam was found to contribute $74 \%$ of the total recharge. Approximately $31 \%$ of the water stored in the reservoir is infiltrated and thus recharges the aquifer. However, the strongest effect on the water levels in the study area is from groundwater abstraction from the well fields. This effect is particularly 
pronounced during dry periods when recharge is low. The present exploitation rate leads to a negative water balance, indicating that the current groundwater use is not sustainable. The dam-induced recharge is not sufficient to compensate for the high abstraction rates. These results indicate that to achieve sustainable management of the groundwater resources in Wadi Bih, an integrated solution must be pursued that considers demand management as well as options to further mitigate the impacts of abstraction.

\section{References}

Al Asam MS (1997) Application of geophysical and geochemical techniques for the assessment of groundwater recharge from Wadi Al Bih Dams, Ras Al Khaimah, United Arab Emirates. Master's Thesis, United Arab Emirates University

Dillon P, Arshad M (2016) Managed aquifer recharge in integrated water resource management. Integrated groundwater management. Springer, Cham, pp 435-452

EAD (2018) Groundwater Atlas of Abu Dhabi Emirate. Environment Agency-Abu Dhabi, Abu Dhabi

Ebraheem AM, Sherif MM, Al Mulla MM et al (2012) A geoelectrical and hydrogeological study for the assessment of groundwater resources in Wadi Al Bih, UAE. Environ Earth Sci 67:845857. https://doi.org/10.1007/s12665-012-1527-0

Freeze RA, Cherry JA (1979) Groundwater: Englewood Cliffs. Prentice-Hall, NJ, p 604

IWACO (1986) Groundwater study. Drilling of deep water wells at various locations in the UAE. Ministry of Environment and Water, United Arab Emirates

Jaafar HH (2014) Feasibility of groundwater recharge dam projects in arid environments. J Hydrol 512:16-26. https://doi.org/10.1016/j.jhydrol.2014.02.054

Maliva R, Missimer T (2012) Arid lands water evaluation and management. Springer Science \& Business Media

McDonald MG, Harbaugh AW (1988) A modular three-dimensional finite-difference ground-water flow model. U. S. Geological Survey

MGGS (1996) Wadi Bih Catchment study for evaluation of water resources and recharge function of the dam. Project 37/96, Internal Report (vol 1). Groundwater development in the northern agricultural region. Ministry of Environment and Water, Dubai, UAE

Missimer TM, Guo W, Maliva RG et al (2015) Enhancement of wadi recharge using dams coupled with aquifer storage and recovery wells. Environ Earth Sci Heidelb 73:7723-7731. https://doi. org/10.1007/s12665-014-3410-7

MOEW, Ministry of Environment and Water (2010) United Arab Emirates water conservation strategy. Ministry of Environment and Water, Dubai, UAE

Murad A, Gaber A, Mahmoud S, Arman H, Al Dhuhoori A (2017) Investigations of upper most soil zone characterizations and its impact in on recharging the shallow groundwater aquifer in arid region: a case study on Wadi El Bih Dam, Ras Al Khaimah, Northern Emirates, United Arab Emirates (UAE). Proceeding of 12th Guld Water Conference, pp 28-30. March 2017, Manama, Bahrain

Murad A, Hussein S, Arman H, Al Dahahn A (2020) Flash floods in the United Arab Emirates (UAE). In: The Fifth International Symposium on Flash Floods in Wadi Systems, ISFF2020, Kyoto University, Kyoto, Japan

Nash JE, Sutcliffe JV (1970) River flow forecasting through conceptual models part I-a discussion of principles. J Hydrol 10:282-290. https://doi.org/10.1016/0022-1694(70)90255-6

Rizk ZS (2015) Why Wadi Al Bih limestone is the most sustainable aquifer in the United Arab Emirates? Int. J. Sustain Water Environ Syst 7(1):21-28 
Rizk ZS, Alsharhan AS (2003) Water resources in the United Arab Emirates. In: Alsharhan AS, Wood WW (eds) Developments in water science. Elsevier, pp 245-264

Rizk ZS, Alsharhan AS, Wood WW (2007) Sources of dissolved solids and water in Wadi Al Bih aquifer, Ras Al Khaimah Emirate, United Arab Emirates. Hydrogeol J 15:1553-1563. https:// doi.org/10.1007/s10040-007-0188-7

Sherif M, Akram S, Shetty A (2009) Rainfall analysis for the Northern Wadis of United Arab Emirates: a case study. J Hydrol Eng 14:535-544. https://doi.org/10.1061/(ASCE)HE.19435584.0000015

Sherif M, Ebraheem A, Shetty A (2017) Groundwater recharge from dams in United Arab Emirates. In: Proceedings of the world environmental and water resources congress 2017, Sacramento, CA

Sherif M, Ebraheem AM, Al Mulla M, Shetty A (2018) New system for the assessment of annual groundwater recharge from rainfall in the United Arab Emirates. Environ Earth Sci 77:412. https://doi.org/10.1007/s12665-018-7591-3

Singh A (2011) Estimating long-term regional groundwater recharge for the evaluation of potential solution alternatives to waterlogging and salinisation. J Hydrol 406:245-255. https://doi.org/ 10.1016/j.jhydrol.2011.07.004

Sorooshian S, Gupta VK (1995) Model calibration. In: Singh VP (ed) Computer models of watershed hydrology. Colorado, pp 23-68

Open Access This chapter is licensed under the terms of the Creative Commons Attribution 4.0 International License (http://creativecommons.org/licenses/by/4.0/), which permits use, sharing, adaptation, distribution and reproduction in any medium or format, as long as you give appropriate credit to the original author(s) and the source, provide a link to the Creative Commons license and indicate if changes were made.

The images or other third party material in this chapter are included in the chapter's Creative Commons license, unless indicated otherwise in a credit line to the material. If material is not included in the chapter's Creative Commons license and your intended use is not permitted by statutory regulation or exceeds the permitted use, you will need to obtain permission directly from the copyright holder.

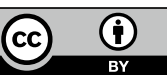

